\title{
ESTABLISHMENT OF SOVIET POWER IN SAMARKAND AND THE BEGINNING OF THE ARMED MOVEMENT AGAINST IT
}

\author{
Botirjon Makhamadalievich Tojibaev \\ PhD in History, Assistant-professor at the department "Theory of civil society" of Andizhan State \\ University, Andizhan region, Republic of Uzbekistan
}

Article DOI: https://doi.org/10.36713/epra5094

\begin{abstract}
This article describes the establishment of Soviet colonialism in Turkestan, including in the Samarkand region, the insidious policy of the Bolsheviks in the country and the emergence of an armed movement against the Soviet regime.

KEYWORDS: the Bolsheviks, the Soviet government, Samarkand, the countryside, the locals, the Korboshi, "basmachilik", the Red Army.
\end{abstract}

\section{INTRODUCTION}

The Turkestan region, including the Samarkand region, had historical factors and serious reasons for the beginning of the armed independence movement in late February and early March 1918. This is primarily due to the fact that the 50-year-old colonial policy of the Russian Empire continued during the new Soviet era. The government of the Turkestan Autonomy in Kokand was violently abolished by the Red Guards and Armenian Dashnaks sent from Tashkent and Skobelev on February 19-22, 1918, and in early March 1918 the chairman of the Council of People's Commissars of Turkestan. The bloodshed caused by Kolesov's military attack on Bukhara left the local population frustrated with the Bolsheviks and the Soviet authorities.

\section{METHODS}

The armed independence movement against the Soviet regime in the Turkestan region began in the Ferghana Valley, or more precisely around Kokand [1.p.48-49]. Shortly afterwards, an armed operation was launched in the Samarkand region against the Soviet government and its military units, the Red Guards and the Red Army. It is acknowledged in the works of almost all historians that the armed movement against the Soviet regime in Turkestan began with the overthrow of the Turkestan Autonomous Government. However, there were a number of other compelling reasons for the start of the armed movement. These were the ideas of the October Revolution of 1917, and the communist ideology promoted by the Bolsheviks and other macro-political forces that seized power by force as a result. The locals were unable to absorb the idea from the beginning and opposed it.

\section{RESULTS AND DISCUSSIONS}

From the earliest days of the new Soviet government, local people were not involved in governing, and their national pride and rights were denied. It was clear from those early days that the Soviet power established by the Bolsheviks in Turkestan was a new form of colonial policy of the 


\section{EPRA International Journal of Research and Development (IJRD)}

Russian Empire. From the earliest days of the new system, the traditions and national values of the indigenous peoples formed over the centuries have been consolidated. Sharia-based judges were abolished, waqf lands were confiscated, and all forms of property were banned [2. p.84-85].

The development and escalation of the armed movement against the Soviet regime in the Samarkand region was also strongly influenced by the specific colonial policy pursued by the Bolsheviks here. The locals were against the invaders and looters, as the Red Army fighters had shown themselves to be real looters and violent people as an invading army, and their life-and-death struggle intensified in Samarkand as well.

As a result of the colonial policy pursued by the Soviet authorities, the political and military situation in the Samarkand region worsened from the beginning of 1918. The armed movement against the Soviet regime, which began in the Turkestan region, has been widespread in the Samarkand region since the spring of 1918. The armed movement in Samarkand (during the Soviet era, this movement was incorrectly called the "Basmachilik" movement, the participants of which were called "Basmachis") was led by such great Kurbashis as Achilbek and Bahrombek.

According to archival documents, Mirza Polvon, Haji Abdulkahhor, Mulla Karimjon, Islam were in Samarkand district and Urgut; Niyozbek (Mamur Niyozbek), Turobbek, Abdulhamidbek, Mulla Hamroqul in Jizzakh district; Kholbotabek, Saidmurod, Norkuzi, Masharif, Turdiboy, Tursunboy, Mulla Javlon, Muhammad Murod in Khojand district and Uratepa; In Kattakurgan district, Karakulbek and in Matcho, Ahmadbek and Asrorkhan led the struggle against the Soviet government and the Red Army units, which were the military forces of the Bolsheviks. The number of young men who fought against the Soviet regime in 1918 was 10,000 , while in 1920 in the Samarkand region alone, 27,000 people fought against the Red Army [3. p.89-90].

The chauvinistic policies of the Soviet government, such as disregarding the local population, not involving them in government, the introduction of forced labor, the mobilization of local horses, the conscription of indigenous peoples into the Red Army, the grain monopoly and the distribution of food. As a result of the Bolshevik policy of "military communism", as in the whole Turkestan region, in the Samarkand region, all peasants and artisans revolted against the Soviet government and the new Bolshevik order, and joined the ranks of patriots.
The leaders of the Turkestan ASSR were forced to admit this fact in time. For example, one of the archival documents of that period states: "We considered the local rich to be among the European bourgeoisie and arrested them, released them from prison only if they paid a certain amount of compensation ...

As for economic activities, we have declared "communes" in areas that are largely agricultural and handicraft. A well-known decree was issued to confiscate all the land and even the smallest handicraft enterprises, leaving many people unemployed and forced to buy a piece of bread. On top of that, in the early days of the revolution, many ginneries were closed, and in Ferghana, in fact, there was a very difficult situation in all areas, both economic, political and organizational. Naturally, all these cadres immediately joined the "invaders".

It should also be noted that at the same time as these measures, we mobilized horses, introduced forced labor, mobilized people to the ranks of the Red Army. At the same time, we continued to implement measures such as the grain monopoly, the distribution of food, as a result of which all peasants and artisans revolted against the Soviet regime, the Soviet order and sided with the "invaders". It should be noted that in 1919-1920 in Ferghana there was not a bandit (robbery), but a popular uprising "[4. p.330-331].

Indeed, in 1918 a popular uprising against the Soviet regime began in the entire Turkestan region, including Samarkand region. This movement intensified in 1919-1920 and extended beyond the Turkestan ASSR to Bukhara and Khorezm. The movement was politically motivated from the outset and was never a bandit or "oppressive" movement. At the same time, the lack of order in the local Soviet offices in Samarkand region, and the disregard for the will of the people, intensified the dissatisfaction of the local population. Representatives of the people - peasants, artisans, merchants, clergy, intellectuals began to side with the independence fighters against the Soviet regime. The movement was politically motivated from the outset and was never a bandit or "oppressive" movement.

The Chairman of the Council of People's Commissars of the Turkestan ASSR, Kaygisiz Atabayev, made a special report on "Printing" at the 5 th session of the Fourth Plenum of the Central Executive Committee of Turkestan on July 18, 1922. "Comrades! Printing is a great reproach in all our affairs in Turkestan, and perhaps in the whole East. So, what explains not only the end of the printing press for 4 years, but also its outbreak in Ferghana, which spread to neighboring regions and covered the 


\section{EPRA International Journal of Research and Development (IJRD)}

entire Samarkand region with a part of Surkhandarya and Turkmenistan provinces? This is explained by the fact that all our work for 4 years was completely contrary to the way of life, customs and traditions of the local population formed over the centuries. Our inability to deal with the situation is a common disease of all of us: as long as we are leaders to one degree or another, this disease has put us in a very difficult position in the eyes of neighboring countries "'[5. p.325].

In his speech K. Otaboev said that the antiSoviet movement was not a banditry, hooliganism or "oppression" movement of a group of people, but a popular uprising against the Bolsheviks, but that Soviet leaders and the Red Army command, the party and the economic leadership were always wrong. "We didn't even know how to properly assess this movement for 4 years, when it was a popular uprising, we called it ${ }^{\text {' }}$ repression '. Printing essentially means looting, and our misinterpretation of this action has led to misguided approaches to solving the problem. And finally in 4 years we have not been able to finish any aspect of this movement.

The Soviet government wanted to end the "repression" movement with both fire and sword at the same time. To this end, large and small villages "poisoned by oppression" were ruthlessly destroyed by the Red Army, and their population became increasingly distant from Soviet rule [6. p.72-78].

The tactics of the Soviet government and the Red Army Command against the independenceists were carried out in disgusting ways. The chairman of the Council of People's Commissars of the Turkestan ASSR acknowledged that the policy of punishment against the insurgents was regular. The hostage-taking experience also lasted much longer. So many people are taken hostage that there is no place to imprison them. Even the mass shooting of hostages will not stop the "oppression" movement. Soon there will be no local officials, ie Muslim communists, who are not suspected of links with the “invaders" [7. p.333-334].

The main driving force of the armed movement in the Samarkand region were farmers, charikors, laborers, artisans and craftsmen. According to one of the leaders of the Turkestan ASSR, farmers and artisans took part in the armed movement [8.p.375]. They were joined by the majority of the city's population: representatives of wealthy families, merchants, mullahs and eshons, kalandars, and some rich people who were Islamic figures. In the ranks of the independents, the educated people who understood black and white were also the majority, and they were many Jadids who were the leading representatives of the Turkestan progressives [1. p.34].

The fighting tactics of the patriots fighting the Red Army were also peculiar. There were many leaders in their ranks who were well acquainted with the local conditions, who knew in advance the conditions of the future battle: the number of Red Army soldiers, the type and number of their weapons, the methods of attack or retreat - all carefully studied in advance. Historical documents from the time testify that the insurgents' intelligence worked brilliantly, "and in battles, in most cases, the invaders, supported by the local population, would win". Because of their familiarity with the local conditions, they moved freely in courtyards and gardens, behind the walls of villages, in neighborhoods and guzars, in mountains and deserts, and in ravines that were difficult for people to reach. Such methods of struggle of the Kurdish groups made it difficult for the Soviet army to carry out military operations against them.

The works of Mirza Salimbek, Muhammad Ali Baljuvani, Ahmadkhan ibn Ismailkhan and others, a number of local historians who lived in the 1920s and 1930s, spoke of patriots who fought for the freedom of the homeland, as well as a group of criminals who committed theft and robbery. These thieves, too, armed with rifles, formed small armed groups and plundered and killed the population.

When talking about the essence and main driving forces of the independence movement in Turkestan, it is necessary to clarify another key issue. Military groups led by the Kurds fought against the enemy for political purposes. But at that time, in 1917-1924, there were various criminal groups, thieves and robbers in the region, including Samarkand region, who were engaged in looting and violence. It is illogical and illiterate to interpret such an armed movement as "oppressive" by placing such thieves and robbers as having nothing to do with the Kurdish groups fighting the Soviet regime, putting them on a par with the independence fighters.

The works of Mirza Salimbek, Muhammad Ali Baljuvani, Ahmadkhan ibn Ismailkhan and others, a number of local historians who lived in the 1920s and 1930s, spoke of patriots who fought for the freedom of the homeland, as well as a group of criminals who committed theft and robbery. These thieves, too, armed with rifles, formed small armed groups and plundered and killed the population. For example, Ahmadkhan ibn Ismailkhan from Samarkand (1873-1924) in his work "Tazkiratul Inqilob" contains information about the people who stole in and around Samarkand in 1917-1918 in the 


\section{EPRA International Journal of Research and Development (IJRD)}

third book of the pamphlet "Statement of vandalism, murder and robbery during the Mensheviks".

In addition to the armed struggle, there were many protests against Soviet rule. Representatives of the people rallied against the Soviet government at the rallies. On May 28, 1918, in the village of Payshanbe, Kattakurgan district, Samarkand region, the Bolsheviks organized a rally in support of the Soviet government, gathering supporters of the new regime. However, at the rally in Kattakurgan district, anti-Soviet forces formed the majority, and these forces made various speeches at the rally organized by the Bolsheviks and dispersed the crowd [9. p.4647].

It is known from history that on September 14, 1918, the Supreme Revolutionary Tribunal was established under the MIC of the Turkestan ASSR. Revolutionary tribunals decided the case in favor of the Soviet government in any case. It was not possible to appeal against the verdict of the tribunals, which also had unlimited powers in the application of punishment. In 1919, the Samarkand Regional Revolutionary Tribunal and its branches in the districts and cities were established. "Enemies of the revolution" were shot by the tribunal without investigation and trial. Emergency "troika" groups (troikas) were also formed, which were also given broad powers. Despite the repressive policy of the Soviet authorities, the independence movement in the Samarkand region reached its peak in the spring of 1919. As a result of the attacks of the young men led by Achilbek Korboshi in the region, the Soviet power was terminated from the Zarafshan oasis to the Turkestan and Zarafshan mountain ranges. The territory of the former Matcho principality (center the village of Oburdon) of the Bukhara Emirate was part of the Samarkand region at that time, where the Red Army frequently conducted raids to establish the Soviet regime. According to the report "Report on the events of August 1918 in Samarkand region" [10.p.56-65], in May-August 1918 in Jizzakh district in dozens of villages and auls in Koktepa and Jausugum volosts, in Kattakurgan district Kalakurgan and Samarkandak volosts In many villages in the Shahob and Chashmaiob volosts of the district, there were various clashes between a "gang of robbers" and representatives of the Soviet authorities [ 10 . p.57-58]. The term "gang of robbers" refers to patriots fighting the Red Army.

On February 2, 1920, the Central Executive Committee of the Soviets of the Turkestan ASSR adopted the Regulations on Revolutionary Tribunals, on February 5, the Provisional Regulations on Regional Revolutionary Committees, and on April
10, 1920, on the Establishment of Regional Extraordinary Commissars. begins to punish ruthlessly.

According to the Statute of Revolutionary Tribunals, revolutionary tribunals can defend the victories of the October Revolution and sentence all those who oppose these achievements to death with any punishment, even the death penalty. According to the charter, regional tribunals were soon established in all oblasts of the Turkestan ASSR, except Tashkent, including Samarkand. The oblast tribunal consisted of a chairman and two members, who were to be appointed by the oblast executive committee or oblast congresses [11.p.1]. It was through these tribunals that the Bolsheviks punished tens of thousands of people in the Samarkand region.

The special troika that worked during this period also brutally punished people. This is evidenced by many archival documents and other sources. For example, in the archive document "Fight against tyranny" there is information about the people killed by the troika.

Shortly before the establishment of revolutionary tribunals and troikas, in March 1918, the "Temporary Regulations on the Establishment of the Workers and Peasants Red Army in Turkestan" were drafted. National units of the Red Army will also be formed on the basis of the charter. A special unit for Muslim Red soldiers in the Red Army was formed in all military units under the leadership of a political leader. Political leaders were appointed by the regional branches of the Bolshevik Party and the Turkestan Provincial Muslim Bureau. In MarchSeptember 1918, a Muslim battalion, a cavalry team, the Tashkent cavalry party squadron, the 1st cavalry artillery route and others were formed in Tashkent.

\section{CONCLUSION}

In short, the armed movement against the Soviet regime in the Samarkand region began in the spring and summer of 1918. Dozens of armed groups led by the Kurds waged a liberation struggle against the Red Guards and the Red Army. Although largescale operations and battles were not observed in 1918-1919, the first stage of the struggle, the armed movement did not cease. The struggle for independence was led by dozens of Korboshis from all major villages and towns of Samarkand. The independence movement in Samarkand was led by such great Kurbashis as Ochilbek and Bahrombek, who fought fiercely against the Red Army of the Turkestan Front and other Soviet military forces in 1918-1919. By this time, the initial phase of the armed movement was over. But the fighting against the Red Army continued later. 


\section{EPRA International Journal of Research and Development (IJRD)}

\section{REFERENCES}

1. Rajabov K.K. The independence movement in the Ferghana Valley: the essence and main stages of development (1918 - 1924). Tashkent: "Yangi nashr", 2015. - 239 p.

2. New history of Uzbekistan. Book 2. Uzbekistan during the Soviet colonial period. Scientific editor M. Juraev. -Tashkent: Shark, 2000. - $688 p$.

3. Urunkhujaev M. Unforgettable days (Memoirs).-Tashkent: State Publishing House of the Uzbek SSR, 1961. - 220 p.

4. National Archive of Uzbekistan, fund R-17, list 1, case 90, pages 330-331.

5. National Archive of Uzbekistan, fund R-17, list 1 , case 90 , page 325 .

6. Paporov Yu. Is the desert sun shining? Translation by Usmon Kochkor // "Youth" (Tashkent). 1990. № 5. - p. 72 - 78

7. National Archive of Uzbekistan, fund R-17, list 1, case 90, pages 333-334.

8. National Archive of Uzbekistan, fund R-17, list 1, case 45, page 375 .

9. Samarkand regional state archive, fund 886 , list 1 , case 5 , pages $46-47$

10. Samarkand regional state archive, fund 1685 , list 1, case 548, pages 56-65

11. Samarkand regional state archive, fund 71, list 1 , case 33, page 1. 